\title{
HUBUNGAN STATUS IMUNISASI CAMPAK DENGAN KEJADIAN CAMPAK PADA ANAK USIA DIBAWAH 5 TAHUN PADA PERISTIWA KLB CAMPAK DI DESA PAGERAGEUNG KECAMATAN PAGERAGEUNG KABUPATEN TASIKMALAYA TAHUN 2000.
}

\author{
dr. Okki Zulkifli, M.Epid
}

\section{A. ABSTRAK}

Di Desa Pagerageung pada bulan Januari - Maret 2000 telah terjadi KLB campak sebesar 98 kasus. Attack Rate (AR) anak golongan umur 0-1 tahun sebesar 8\%, golongan umur 1-4 tahun 11,1\%, golongan umur 5-9 tahun 20,3\% dan golongan umur 10-14 tahun 12\%. Dari 98 orang yang menderita campak 61 orang ( 62,24\%) pada anak yang diimunisasi, dan 37 orang (37,76\%) pada anak yang tidak diimunisasi, dengan Efikasi Vaksin sebesar 58,9\%. Hasil analisis bivariat didapat $O R=2,93$ dan $P=0,00$. Cakupan imunisasi campak di Desa Pagerageung selama lima tahun terakhir terjadi fluktuasi dan rata-rata sudah diatas angka Nasional (90\%) yakni pada tahun 1995 sebesar 75,17\%, tahun 1996 sebesar 90,78\%, tahun 1997 sebesar 100\%, tahun 1998 sebesar 88,32\% dan tahun 1999 sebesar 95,75\% ( Duski, 2000). Tujuan dalam penelitian ini adalah untuk mengetahui hubungan status imunisasi campak dengan kejadian campak pada anak usia dibawah 5 tahun pada peristiwa KLB campak di Desa Pagerageung Kecamatan Pagerageung Kabupaten Tasikmalaya tahun 2000.

Desain yang digunakan adalah penelitian analitik dengan pendekatan Historical Cohort (Kohor Retrospektif). Perkiraan hipotesa resiko relatif $(R R)=$ 2,44 ( hasil dari investigasi KLB campak di Desa Pagerageung tahun 2000 ). Perkiraan sampel minimal $n=77$ ( Tabel Simpel Size RR). Pada penelitian ini didapatkan jumlah yang terpapar sebanyak 84. Dengan perbandingan 1: 1 maka ditetapkan jumlah sampel sebanyak 168. Data primer dikumpulkan melalui wawancara terstruktur dengan menggunakan kuesioner dan dilakukan observasi untuk melihat kepadatan penghunian dan ventilasi rumah oleh Peneliti dan dibantu oleh tenaga dari Puskesmas. Hasil penelitian ini adalah Ada hubungan status imunisasi, kepadatan penghuni serta ventilasi dengan dengan kejadian campak dan secara statistik bermakna. Faktor pendidikan, pengetahuan dan sikap ibu tidak ada hubungan dengan kejadian campak.Efikasi vaksin untuk usia anak dibawah 5 tahun masih rendah (50\%) dan ini menunjukkan kedayagunaan vaksin campak yang rendah.

Perlu dilakukan penelitian lebih lanjut tentang penanganan vaksin, pelaksanaan jalur cold chain, suplai vaksin, cara pemberian vaksinasi dan sebagainya dengan metoda observasi yaitu bagaimana hal ini dilaksanakan dilapangan, mengapa hal ini terjadi, masalah-masalah apa yang dihadapi.

Kata Kunci : Status imunisasi, kejadian campak. 


\section{B. PENDAHULUAN}

Campak adalah suatu penyakit infeksi viral akut yang mudah ditularkan, sehingga hampir semua anak yang dilahirkan akan pernah ketularan penyakit ini, sebagian besar sebelum mencapai umur 5 tahun (Gunawan, S, 1987).

Di Desa Pagerageung pada bulan Januari - Maret 2000 telah terjadi KLB campak sebesar 98 kasus. Attack Rate (AR) anak golongan umur 0-1 tahun sebesar 8\%, golongan umur 1-4 tahun 11,1\%, golongan umur 5-9 tahun $20,3 \%$ dan golongan umur 10-14 tahun 12\%. Dari 98 orang yang menderita campak 61 orang ( $62,24 \%$ ) pada anak yang diimunisasi, dan 37 orang ( $37,76 \%$ ) pada anak yang tidak diimunisasi, dengan Efikasi Vaksin sebesar 58,9\%. Hasil analisis bivariat didapat $\mathrm{OR}=2,93$ dan $\mathrm{P}=0,00$. Cakupan imunisasi campak di Desa Pagerageung selama lima tahun terakhir terjadi fluktuasi dan rata-rata sudah diatas angka Nasional ( 90\% ) yakni pada tahun 1995 sebesar 75,17\%, tahun 1996 sebesar 90,78\%, tahun 1997 sebesar $100 \%$, tahun 1998 sebesar 88,32\% dan tahun 1999 sebesar 95,75\% ( Duski, 2000 ).

Tujuan dalam penelitian ini adalah untuk mengetahui hubungan status imunisasi campak dengan kejadian campak pada anak usia dibawah 5 tahun pada peristiwa KLB campak di Desa Pagerageung Kecamatan Pagerageung Kabupaten Tasikmalaya tahun 2000 .

\section{METODOLOGI PENELITIAN}

\section{Desain Penelitian}

Desain yang digunakan adalah penelitian analitik dengan pendekatan Historical Cohort

(Kohor

\section{a. Populasi dan Sampel}

1) Populasi

Anak usia dibawah 5 tahun yang tinggal di wilayah Puskesmas Pagerageung

Desa Pagerageung

Kecamatan Pagerageung Kabupaten Tasikmalaya.

\section{2) Sampel}

Anak usia dibawah 5 tahun yang tinggal dan tercatat pada waktu peristiwa KLB campak di Desa Pagerageung Kecamatan Pagerageung pada bulan Januari - Maret 2000.

3) Besar Sampel

Ditentukan dari sampel size determinantion dari WHO (Stephen K. Lwanga et al, 1997) dengan dasar rumus untuk uji hipotesis Resiko Relatif.

Perhitungan sampel minimal dilakukan secara manual diperoleh jumlah sampel sebagai berikut :

Retrospektif). 
Tabel. Perkiraan Besar Sampel Minimal Hubungan Status Imunisasi Campak dengan Kejadian Campak dan Faktor - Faktor yang Mempengaruhinya.

\begin{tabular}{|c|c|c|}
\hline Var. Independen & $\mathrm{P} 2$ & $\begin{array}{c}\mathrm{n} \\
\text { minmal }\end{array}$ \\
\hline Status imunisasi & 0,1 & 77 \\
\hline Pendidikan Ibu & 0,66 & 32 \\
\hline Pengetahuan Ibu & 0,82 & 35 \\
\hline Sikap Ibu & 0,15 & 59 \\
\hline Kepadatan hunian & 0,36 & 74 \\
\hline Ventilasi hunian & 0,30 & 42 \\
\hline
\end{tabular}

Perkiraan hipotesa resiko relatif ( $\mathrm{RR}$ ) $=2,44$ ( hasil dari investigasi KLB campak di Desa Pagerageung tahun 2000 ). Perkiraan sampel minimal $\mathrm{n}=77$ ( Tabel Simpel Size RR ). Pada penelitian ini didapatkan jumlah yang terpapar sebanyak 84. Dengan perbandingan 1: 1 maka ditetapkan jumlah sampel sebanyak 168.

\section{b. Pengumpulan Data}

Data primer dikumpulkan melalui wawancara terstruktur dengan menggunakan kuesioner dan dilakukan observasi untuk melihat kepadatan penghunian dan ventilasi rumah oleh Peneliti dan dibantu oleh tenaga dari Puskesmas.

\section{c. Pengolahan Data}

1. Editing

2. Koding Data

3. Pemindahan Data ke Komputer

\section{d. Analisa Data}

\section{Analisa Univariat}

Untuk memperoleh gambaran distribusi frekuensi dan proporsi dari berbagai karakteristik atau variabel yang diteliti, baik variabel terikat maupun variabel bebas. 


\section{Analisa Bivariat}

Bertujuan untuk menguji hipotesis antara variabel bebas dan variabel terikat untuk mengestimasi pengaruh masing-masing faktor yang diteliti ( variabel bebas ) terhadap kejadian campak di Desa Pagerageung maka dipakai analisis Resiko Relatif ( RR ), untuk kelompok exposed ( kelompok yang tidak diimunisasi ) dan kelompok non exposed ( kelompok yang diimunisasi ).

\section{Analisis Multivariat}

Untuk mengetahui besar pengaruh seluruh variabel bebas terhadap variabel terikat, perlu dilakukan analisis multivariat dengan menggunakan logistik regression, selanjutnya dilakukan uji interaksi dan counfonding. Uji interaksi dilakukan dengan membandingkan model tanpa interaksi dengan model yang memasukkan interaksi secara satu persatu, dengan uji likelihood ratio. Jika kesimpulan dari nilai $\mathrm{P}$ menunjukkan perbedaan makna $(\mathrm{P}<0,05)$, maka dua variabel tersebut berinteraksi.

\section{HASIL PENELITIAN}

\section{A. Analisa Univariat}

\section{Komponen Kejadian}

Sebagian besar anak responden tidak menjadi sakit yaitu $84,52 \%$ termasuk katagori tidak sakit dan $15,48 \%$ termasuk katagori sakit. Terlihat perbedaaan yang cukup besar antara kelompok terpapar dengan kelompok tidak terpapar.

Pada kelompok terpapar ( tidak imunisasi ) 22,62\% termasuk katagori sakit, sedangkan kelompok tidak terpapar ( diimunisasi ) $8,33 \%$.

\section{Faktor Ibu}

\section{a. Pendidikan Ibu}

Sebagian besar responden berpendidikan tamat SD $67,26 \%$ dan proporsi terkecil 7,14\% adalah responden tamat perguruan tinggi. Terlihat ada perbedaan proporsi terpapar dengan tidak terpapar, terutama pada kelompok yang berpendidikan tamat Perguruan Tinggi. Pada kelompok terpapar tamat Perguruan Tinggi $3,57 \%$, sedangkan kelompok tidak terpapar $10,71 \%$.

\section{b. Pengetahuan Ibu}

Sebagian besar responden memiliki pengetahuan tentang penyakit campak, termasuk dalam katagori pengetahuan baik yaitu $62,50 \%$ dan $37,50 \%$ berpengetahuan kurang. Terlihat perbedaan antara pengetahuan kelompok terpapar dengan kelompok tidak terpapar. Pada kelompok terpapar yang berpengetahuan kurang 48,8\%, sedangkan pada kelompok tidak terpapar $26,19 \%$.

c. Sikap Ibu
Sikap responden terhadap
penyakit campak $42,86 \%$
termasuk dalam katagori kurang
dan 57,14\% termasuk dalam
katagori baik. Terlihat ada
sedikit perbedaan sikap antara
kelompok terpapar dengan tidak
terpapar. Kelompok terpapar
yang memiliki sikap kurang
$45,24 \%$, sedangkan pada
kelompok tidak terpapar
$40,48 \%$.

3. Faktor Lingkungan

a. Kepadatan Hunian

Sebagian besar tempat tinggal responden cukup baik yaitu 
$25,60 \%$ termasuk katagori padat dan $74,40 \%$ termasuk katagori tidak padat. Terlihat sedikit perbedaan tempat tinggal kelompok terpapar dengan kelompok tidak terpapar. Kelompok terpapar dengan tempat tinggal katagori padat 33,33\%, sedangkan kelompok tidak terpapar $17,86 \%$.

\section{b. Ventilasi Hunian}

Sebagian besar tempat tinggal responden memiliki ventilasi yaitu $51,79 \%$ termasuk katagori tidak baik, 48,21\% termasuk katagori baik, antara kelompok terpapar dengan kelompok tidak terpapar ventilasinya relatif tidak ada perbedaan.

\section{B. Analisa Bivariat}

\section{Status Imunisasi}

Ada hubungan antara status imunisasi anak dengan kejadian campak dengan nilai Risk Ratio 2,71 ( 95\% CI $=1,20-6,11)$ dan nilai $\mathrm{P}=0,0189$.

\section{Faktor Lingkungan}

a. Kepadatan Hunian

Ada hubungan antara kepadatan hunian dengan kejadian campak dengan nilai Risk Ratio 2,49 ( 95\% $\mathrm{CI}=1,25-4,96)$ dan nilai $\mathrm{P}=$ 0,0178 .

\section{b. Ventilasi Hunian}

Ada hubungan antara ventilasi hunian dengan kejadian campak dengan nilai Risk Ratio 2,53 ( $95 \% \mathrm{CI}=1,12-5,69$ ) dan nilai $\mathrm{P}=0,0315$.

\section{Faktor Ibu}

a. Pendidikan Ibu

Pendidikan ibu tidak dapat dibuktikan mempunyai hubungan dengan kejadian campak karena mempunyai nilai Risk Ratio melampui nilai 1 yaitu $0,75-4,72$ dan nilai $\mathrm{P}=0,2397(\mathrm{P}>0,05)$.

\section{b. Pengetahuan Ibu}

Pengetahuan ibu tidak dapat dibuktikan mempunyai hubungan dengan kejadian campak karena mempunyai nilai Risk Ratio melampui nilai 1 yaitu $0,60-2,49$ dan nilai $\mathrm{P}=0,7410(\mathrm{P}>0,05)$.

\section{c. Sikap Ibu}

Sikap ibu tentang penyakit campak tida ada hubungan dengan kejadian campak, karena nilai Risk Ratio melampui nilai 1 yaitu $0,40-1,73$ dan nilai $\mathrm{P}=0,7816(\mathrm{P}>0,05)$. 


\section{Analisa Multivariat}

\section{Seleksi Variabel}

Analisis multivariat dengan regresi logistik bertujuan untuk memperoleh model yang paling sesuai yang dapat menggambarkan hubungan antara variabel terikat dengan variabel bebas.

Tabel : Distribusi Variabel Bebas Yang Mnejadi Calon Kandidat Model

\begin{tabular}{|c|c|c|c|}
\hline $\begin{array}{c}\text { VARIAB } \\
\text { EL }\end{array}$ & $\begin{array}{c}\text { RISK } \\
\text { RATI } \\
\text { O }\end{array}$ & $\begin{array}{c}\mathbf{9 5} \\
\text { \% } \\
\text { CI }\end{array}$ & P \\
\hline Imunisasi & 2,71 & 1,2 & 0,01 \\
& & $0-$ & 89 \\
& & 1 & \\
\hline $\begin{array}{c}\text { Kepadata } \\
\text { n }\end{array}$ & 2,49 & 1,2 & 0,01 \\
& & $5-$ & 78 \\
& & 4,6 & \\
\hline $\begin{array}{c}\text { Ventilasi } \\
\end{array}$ & 2,53 & 1,1 & 0,03 \\
& & $2-$ & 15 \\
& & 9,6 & \\
\hline $\begin{array}{c}\text { Pendidika } \\
\text { n }\end{array}$ & 1,88 & 0,7 & 0,23 \\
& & $5-$ & 79 \\
& & 2 & \\
\hline
\end{tabular}

Hasil analisis multivurat dengan metoda seleksi Back Ward diperoleh hasil sebagai berikut :
Tabel : Hasil Analisis Regresi Ganda Logistik Antara Variabel Terikat Dengan Seluruh Variabel Bebas (yang masuk dalam model)

\begin{tabular}{|l|l|l|l|l|}
\hline VARIABEL & $\mathrm{B}$ & SE & WALD & SIG \\
\hline Imunisasi & 1,1377 & 0,5020 & 5,1369 & 0,0234 \\
\hline Kepadatan & 1,1909 & 0,4845 & 6,0164 & 0,0164 \\
\hline Ventilasi & 1,4845 & 0,5203 & 8,1416 & 0,0043 \\
\hline Pendidikan & 0,9880 & 0,5580 & 3,1351 & 0,0766 \\
\hline Constant & $-0,3877$ & 0,4912 & 0,6229 & 0,4300 \\
\hline
\end{tabular}

Dari tabel tersebut diatas tampak terlihat tiga variabelyang menunjukkan hubungan sangat bermakna dibanding dengan variabel lainnya yaitu variabel imunisasi dengan nilai $\mathrm{P}=0,02$ dan $\mathrm{RR}=$ 3,12, variabel kepadatan dengan nilai $\mathrm{P}=0,01$ dan $\mathrm{RR}=$ 3,30 , serta variabel ventilasi dengan nilai $\mathrm{P}=0,00$ dan $\mathrm{RR}=$ 4,41

\section{Penilaian Interaksi dan Confounding}

Analisis interaksi adalah analisis antara 2 variabel faktor risiko, apakah saling memperkuat atau memperlemah. ( Bastaman, 1999 ).

Dengan perhitungan matematik dan jika semua variabel adalah merupakan faktor resiko, dimana anak tidak diimunisasi campak, tempat tinggal yang padat dan ventilasi yang kurang, maka peluang anak untuk menderita penyakit campao adalah $98 \%$, sedangkan jika semua variabel bukan merupakan faktor resiko, peluang anak untuk menderita penyakit campak adalah $48,5 \%$. 
Jika semua variabel pengontrol dianggap sama ( X2 $=\mathrm{X} 3=0$, tidak padat dan ventilasi baik ) maka didapatkan hasil sebagai berikut bila status imunisasi ( ), tidak padat dan ventilasi baik, diperoleh insiden untuk menderita campak sebesar $82 \%$ dan bila status imunisasi $(+)$, tidak padat dan ventilasi baik, diperoleh insiden untukbmenderita campak sebesar $48 \%$.

\section{E. PEMBAHASAN}

\section{Hubungan Status Imunisasi Campak dengan Kejadian Campak}

Campak merupakan suatu penyakit infeksi viral akut yang mudah ditularkan, sehingga hampir semua anak yang dilahirkan pernah ketularan penyakit ini, sebagian besar sebelum mencapai umur 5 tahun. Imunisasi campak merupakan cara yang paling cost efektif untuk menanggulangi penyakit campak di masyarakat (Gunawan, S, 1987).

Hasil penelitian di Desa Pagerageung tahun 2000, proporsi anak yang menderita campak lebih banyak (22,6\%) pada anak yang tidak diimunisasi campak dibanding anak yang diimunisasi campak $(8,33 \%)$. Pada analisis bivariat diperoleh hasil, status imunisasi campak dengan Resiko Relatif (RR) 2,71 yang berati anak yang tidak diimunisasi campak berisiko, 2,71 kali lebih besar untuk menderita campak dibanding anak yang diimunisasi, dan secara ststistik bermakna $(\mathrm{P}=0,02)$. Pada analisis multivariat, setelah dikontrol kepadaaan dan ventilasi anak yang tidak diimunisasi campak berisiko 3,2 kali lebih besar untuk menderita campak dibanding anak yang diimunisasi.
Ini sesuai denga hasil penelitian Purnoma, H. 1993 di Jakarta Selatan. Pada kelompok tidak diimunisasi sebesar 2,1 kali $(\mathrm{P}=0,01)$ berpeluang untuk menderuta penyakit campak dari pada anak yang telah diimunisasi. Disini secara stastitik ada perbedaan, ini kemungkinan karena daerah, waktu dan metoda peneltian yang berbeda.

\section{Hubungan Faktor Independen Lain dengan Kejadian Campak}

\section{Faktor Lingkungan}

Lingkungan yang kurang baik akan mempermudah penularan penyakit campak dapat dilihat dari kepadatan dan ventilasi hunian. Hasil penelitian di Desa Pagerageung tahun 2000 ada hubungan antara kepadatan ( $\mathrm{P}=0,01, \mathrm{RR}=3,28)$, ventilasi hunian ( $\mathrm{P}=0,01, \mathrm{RR}=3,87$ ) dengan kejadian campak dan secara statistik bermakna. Hasil penelitian Purnomo, H. di Jakarta Selatan (1993) pada kelompok padat hunian sebesar 5,27 kali berpeluang untuk menderita campak dari pada anak yang tinggal pada hunian yang tidak padat dan secara statistik bermakna. Pada kelompok ventilasi kurang sebesar 2,90 kali berpeluang untuk menderita campak dari pada anak yang tinggal di rumah dengan ventilasi baik, dan secara statistik bermakna $(\mathrm{P}=0,01)$.

Dibley, 1987 berpendapat, faktor yang dapat berkontribusi terjadinya campak pada anak-anak adalah : rumah tinggal yang padat penghuninya, kontruksi yang jelek dan ventilasi yang buruk. Pada analisis multivariat dimana kepadatan dan ventilasi hunian merupakan variabel kontrol untuk status imunisasi terhadap kejadian campak, ternyata kepadatan dan ventilasi hunian tidak berinteraksi dengan status imunisasi, sedangkan ventilasi hunian merupakan confounding. Melihat hasil penelitian di atas dan menurut pendapat Dibley ternyata kepadatan dan ventilasi hunian sangat berperan untuk 
terjadinya campak, maka diperlukan adanya penataan rumah sehat.

2. Faktor Ibu

a. Pendidikan Ibu

Proporsi anak yang menderita campak lebih besar pada Ibu yang berpendidikan rendah, dibanding Ibu yang berpendidikan tinggi dengan Resiko Relatif sebesar 1,88, yang berarti anak yang Ibunya berpendidikan rendah beresiko 1,88 kali lebih besar untuk menderita campak dibanding anak dengan Ibu yang yang berpendidikan tinggi, akan tetapi secara statistik tidak ada hubungan antara pendidikan Ibu dengan kejadian campak $(0,2397)$.

\section{b. Pengetahuan dan Sikap Ibu}

Proporsi anak yang menderita campak lebih besar pada Ibu yang berpengetahuan kurang tentang campak dibanding Ibu yang berpengetahuan baik dengan Resiko Relatif sebesar 1,25 yang berarti anak dengan Ibu yang berpengetahuan kurang 1,25 kali lebih besar untuk menderita campak dibanding anak dengan Ibu berpengetahuan baik, tetapi secara ststistik tidak ada huungan antara pengetahuan Ibu dengan kejadian campak $(0,60808)$. Sedangkan menderita campak dengan sikap Ibu relatif sama dan secara statistik tidak ada hubungan antara sikap Ibu dengan kejadian campak $(0,8545)$.

\section{F. KESIMPULAN DAN SARAN}

\section{Kesimpulan}

1. Ada hubungan status imunisasi campak dengan kejadian campak dan secara statistik bermakna. Dimana anak yang tidak diimunisasi campak 3,2 kali lebih besar berisiko untuk menderita campak dibanding anak yang diimunisasi. Terjadi KLB campak karena cakupan imunisasi campak yang rendah $(75,17 \%)$.

2. Ada hubungan kepadatan hunian dengan kejadian campak dan secara statistik bermakna. Dimana anak yang tinggal dengan rumah padat 2,5 kali lebih besar untuk menderita campak dibanding anak yang tinggal dengan ruamh tidak padat.

3. Ada hubungan ventilasi hunian dengan kejadian campak dan secara statistik bermakna. Dimana anak yang tinggal dengan ventilasi tidak baik 2,5 kali lebih besar untuk menderita campak dibanding anak yang tinggal dirumah dengan ventilasi baik.

4. Faktor pendidikan, pengetahuan dan sikap ibu tidak ada hubungan dengan kejadian campak.

5. Efikasi vaksin untuk usia anak dibawah 5 tahun masih rendah $(50 \%)$ dan ini menunjukkan kedayagunaan vaksin campak yang rendah.

\section{Saran}

\section{Bagi Puskesmas}

a. Meningkatkan cakupan imunisasi campak khususnya daerah kantong ( $\mathrm{UCI}=100 \%$ ).

b. Kepala Puskesmas mengusulkan ke Kabupaten melalui Camat program rumah sehat terutama daerah (desa) potensi wabah.

\section{Bagi Dinas Kesehatan Kabupaten}

Meningkatkan supervisi ke lapangan ( Puskesmas ) mengenai pelaksanaan imunisasi

\section{Bagi Peneliti Selanjutnya}

Perlu dilakukan penelitian lebih lanjut tentang penanganan vaksin, pelaksanaan jalur cold chain, suplai vaksin, cara pemberian vaksinasi dan sebagainya dengan metoda observasi yaitu bagaimana hal ini dilaksanakan dilapangan, mengapa hal ini terjadi, masalah-masalah apa yang dihadapi. 


\section{G. DAFTAR PUSTAKA}

Adisasmita,Asri C,1993. Hubungan Antara Host, Agent, dan Lingkungan Sebagai Pendekatan Epidemiologi. Bahan kuliah Epidemiologi I.

Aaby, P. et. al. 1987. Key Issue in Measles Immunization Research : a review of the liturature. Geneva WHO, Expanded Programme on Immunization.

Depkes RI, 1994. Petunjuk Teknis Reduksi Campak di Indonesia. Departemen Kesehatan Republik Indonesia, Jakarta.

Dinas Provinsi Jawa Barat, 1996. Pedeoman Sistim Kewaspadaan Dini dan Penanggulangan Kejadian Luar Biasa. Dinas Kesehatan Provinsi Jawa Barat, Bandung.

Dinas Provinsi Jawa Barat, 1999. Profil Kesehatan Jawa Barat Tahun 1998. Dinas Kesehatan Provinsi Jawa Barat, Bandung.

Depkes RI, 1994 Pencatatan dan Pelaporan Kasus Campak. Direktorat Jenderal P2M dan PLP,Jakarta.

Anonim. 1994. Petunjuk Teknis Reduksi Campak di IndonesiaDirektorat Jenderal P2M dan PLP,Jakarta.

Depkes RI, 1994 Pelaporan Uji Coba Petunjuk Teknis Reduksi Campak di Kabupaten Serang. Direktorat Jenderal P2M dan PLP,Jakarta.

Basuki, B. 1999. Aplikasi Metode Kasus Kontrol. Bagian Ilmu Kedokteran Komunitas. Fakultas Kedokteran Universitas Indonesia, Jakarta.

Budiarso, L. R. 1986. Survei Kesehatan Rumah Tangga. Departemen Kesehatan Republik Indonesia, Jakarta (hal 151-168)

Chandra, B. 1996. Pengantar Prinsip dan Metode Epidemiologi. Buku Kedokteran ECG.
Cruickshank. 1961. The Back Grond To Immunization In : The Role of Immunization in Communicable Desease Control WHO Geneva.

Duski, O.Z. 1999. Surveilans Epidemiologi Penyakit Campak di Kabupaten Tasikmalaya Tahun 1995-1998. Program Magister Epidemiologi Kekhususan Lapangan Angkatan III. Program Studi Epidemiologi, Pasca SarjanaUniversitas Indonesia, Jakarta. 